\title{
EFISIENSI TEKNIS, PERTUMBUHAN TEKNOLOGI DAN TOTAL FAKTOR PRODUKTIVITAS PADA INDUSTRI MENENGAH DAN BESAR DI INDONESIA
}

\author{
Muhammad Fazri $^{1}$, Hermanto Siregar ${ }^{2}$ Nunung Nuryartono ${ }^{2}$ \\ ${ }^{1}$ Mahasiswa Pascasarjana Departemen Ilmu Ekonomi, FEM IPB \\ ${ }^{2}$ Dosen Departemen Ilmu Ekonomi, Institut Pertanian Bogor
}

\begin{abstract}
Indonesia's economic growth this decade has good development. Not only growing but also more stable than before the reform era which is visible from the persistence of Indonesia at the level of positive growth during the economic crisis of 2008. Growth was good was followed by a change in the proportion of manufacturing industry in Indonesia which, if seen followed by a decrease in the production of some subsector indices industry. Total factor productivity (TFP) is one measure to look at other factors apart from the impact on production inputs such as technical efficiency and technological growth. In this study, in addition to trying to calculate TFP in some manufacturing industries subsector, in this study also wants to see the value of technical efficiency and the growth of the technology is a component of TFP calculations by the method of Stochastic Frontier Analysis (SFA). The results show that there is growing value of technical efficiency in some industries and most industries experienced relatively low growth of the technology. In the era before and after the crisis most of the industry has increased TFP growth but some industry decreased TFP growth.
\end{abstract}

Keywords: SFA, Technical efficiency, Technological growth, TFP

\section{PENDAHULUAN}

Indonesia merupakan negara yang memiliki tingkat pertumbuhan ekonomi yang cukup stabil. Semenjak krisis tahun 1998 ekonomi Indonesia terus mengalami peningkatan. Tidak hanya mengalami peningkatan namun juga terus mengalami penguatan dari sisi ketahanan ekonomi. Hal tersebut dilihat dari nilai pertumbuhan ekonomi yang masih cukup tinggi disaat krisis ekonomi yang terjadi pada tahun 2008 . Gambar 1 menunjukkan Indonesia memiliki pertumbuhan positif pada tahun 2008 dibandingkan dengan negara lain seperti Thailand, Malaysia dan Jepang.
Pertumbuhan ekonomi yang membaik diikuti dengan pergeseran sektor yang memberikan kontribusi terbesar terhadap pendapatan Nasional di Indonesia. Semenjak Orde baru dan awal reformasi sektor yang memberi kontribusi terbesar terhadap pendapatan Nasional yaitu sektor Industri pengolahan. Sektor ini memberikan kontribusi hingga $27,75 \%$ pada tahun 2000. Namun perlahan-lahan pergesaran sektor mulai terlihat. Kontribusi sektor pengolahan terhadap pendapatan nasional menurun dan beralih kepada lima sektor lainnya seperti, Bangunan, perdagangan, transportasi, dan jasa-jasa. 


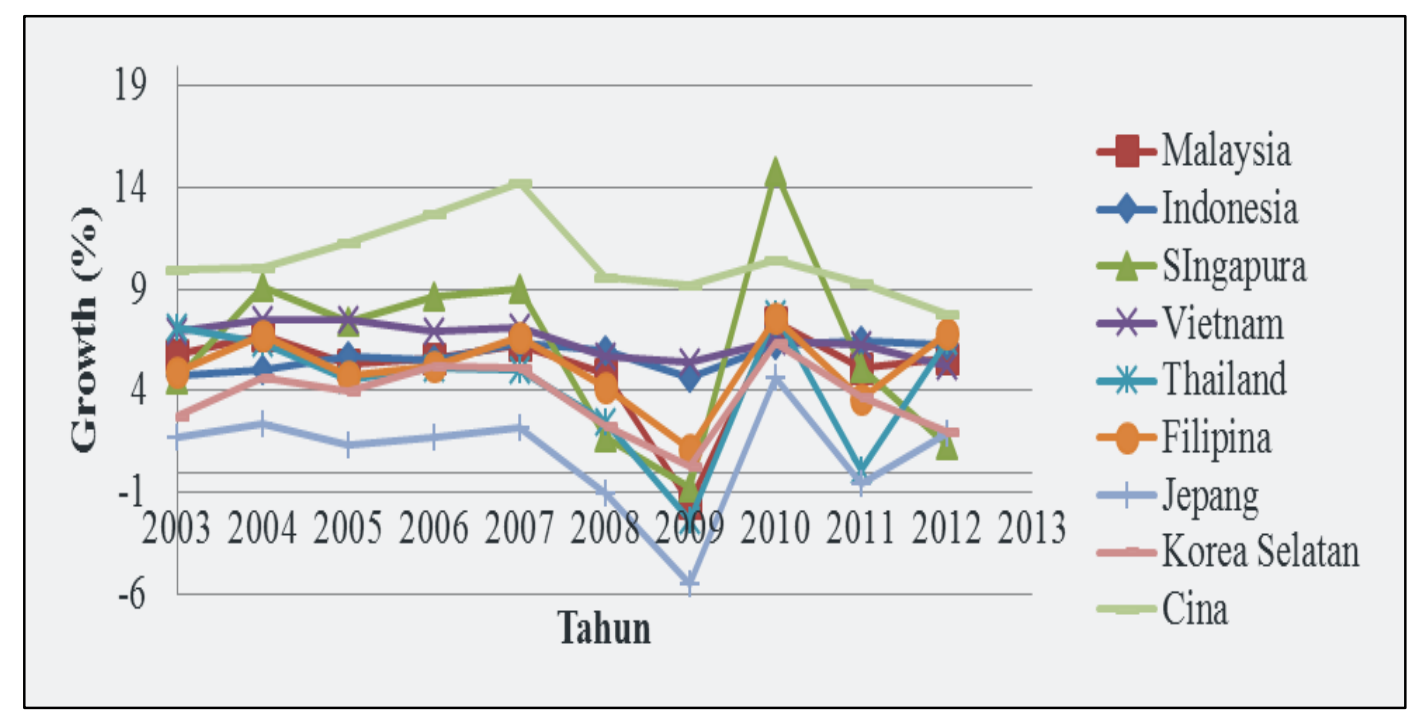

Sumber : World Development Indicator (2013)

Gambar 1 Pertumbuhan Ekonomi Sembilan Negara ASEAN +3

Penurunan proporsi tersebut diikuti oleh Penurunan indeks produksi pada industri pengolahan. Penurunan tersebut disebabkan beberapa industri mengalami penurunan produktivitas. Produktivitas merupakan sebuah alat pengukuran untuk melihat sejauh mana efisiensi dan efektifitas yang dihasilkan oleh input dalam menghasilkan output. Total faktor produktivitas merupakan salah satu ukuran untuk mengukur bagaimana pengaruh lainnya terhadap output yang dihasilkan selain dari output. Menurut Romer (1986) terdapat tiga komponen dalam perhitungan TFP yaitu efisiensi teknis, skala usaha dan peruhan teknologi.

Beberapa penelitian telah mencoba menghitung nilai TFP khususnya pada industri menegah dan besar di Indonesia. Seperti pada Sirait (2007) dan Modjo (2006) namun selain penelitian tersebut hanya sampai pada tahun 2000 hingga 2003. Penelitian tersebut hanya mencakup keseluruhan industri sedang dan besar di Indonesia. Karena itu perlu dilakukan penelitian terkait Efisiensi Teknis dan TFP pada tingkat sub sektor Industri.

\section{TINJAUAN PUSTAKA}

\section{Model Pertumbuhan Solow}

Teori pertumbuhan neo-klasik berkembang pada tahun 1950-an. Secara sederhana teori pertumbuhan neo-klasik yang dipopulerkan oleh Solow yang menyatakan bahwa faktor produksi tenaga kerja dan kapital merupakan faktor utama penentu pertumbuhan ekonomi suatu negara. Faktor produksi lain yang berpengaruh terhadap produksi ditentukan oleh TFP yang sering dinyatakan sebagai ukuran kemajuan teknologi (technological progress). TFP merupakan ukuran dari produktivitas faktor produksi yang tidak dapat diketahui apakah berasal dari faktor tenaga kerja atau capital Romer (1986).

Teori pertumbuhan neo-klasik awal memiliki asumsi sederhana yaitu tidak ada kemajuan teknologi. Fungsi produksi (Y) hanya ditentukan oleh faktor produksi tenaga kerja (L) dan kapital (K).

$\mathrm{Y}=\mathrm{F}(\mathrm{K}, \mathrm{L})$ 
Kenaikan kedua faktor produksi sebesar $\Delta \mathrm{K}$ dan $\Delta \mathrm{L}$ akan meningkatkan output. Kenaikan output dengan menggunakan produk marjinal dari kedua faktor produksi dijelaskan dengan persamaan:

$\Delta \mathrm{Y}=(\mathrm{MPK} \times \Delta \mathrm{K})+(\mathrm{MPL} \times \Delta \mathrm{L}) \ldots(2)$

Produk marjinal tenaga kerja (marginal product of labor) atau MPL adalah jumlah output tambahan yang didapat perusahaan dari satu unit tenaga kerja tambahan dengan modal tetap. Produk marjinal modal (marginal product of capital), atau MPK, adalah jumlah output tambahan yang perusahaan dapatkan dari unit modal tambahan, dengan jumlah tenaga kerja konstan

Persamaan (2) juga dapat ditulis sebagai berikut:

$\frac{\Delta \mathrm{Y}}{y}=\frac{M P K \times K}{Y} \frac{\Delta \mathrm{K}}{K}+\frac{M P L \times L}{L} \frac{\Delta \mathrm{L}}{L}$

Bentuk persamaan

menunjukkan hubungan antara tingkat pertumbuhan output, dengan tingkat pertumbuhan kapital, dan tingkat pertumbuhan tenaga kerja, menujukkan bagian kapital dari output sedangkan menujukkan bagian tenaga kerja dari output. Dengan asumsi bahwa fungsi produksi memiliki skala pengembalian konstan maka, persamaan (3) dapat ditulis sebagai berikut:

$\frac{\Delta \mathrm{Y}}{y}=\alpha \frac{\Delta \mathrm{K}}{K}+\beta \frac{\Delta \mathrm{L}}{L}$

Robert M. Solow dalam Mankiw (2003) telah memasukkan perubahan teknologi yang dilambangkan dalam huruf A dalam fungsi produksi, dimana perubahan tersebut juga mencerminkan teknologi yang digunakan untuk mengubah modal dan tenaga kerja menjadi output. Jadi, perubahan teknologi memengaruhi fungsi produksi, karena teknologi produksi yang ada menentukan berapa banyak output diproduksi dan jumlah modal dan tenaga kerja tertentu. Persamaan mengganakan tingkat teknologi terbaru (TFP) adalah sebagai berikut:

$\mathrm{Y}=\mathrm{A} F(\mathrm{~L}, \mathrm{~K})$

Simbol A adalah ukuran dari tingkat penggunaan teknologi atau disebut juga TFP. Dengan demikian peningkatan produksi tidak hanya diakibatkan oleh peningkatan tenaga kerja dan kapital, tetapi juga oleh kenaikan TFP.

$\frac{\Delta \mathrm{Y}}{y}=\alpha \frac{\Delta \mathrm{K}}{K}+\beta \frac{\Delta \mathrm{L}}{L}+\frac{\Delta \mathrm{A}}{A}$.

Persamaan (6) mengukur tiga sumber pertumbuhan yaitu perubahan jumlah kapital, perubahan jumlah tenaga kerja, dan perubahan TFP.

\section{Teori Pertumbuhan Endogen}

Teori pertumbuhan endogen (endogenous growth theory) muncul untuk mengatasi beberapa permasalahan yang terdapat pada pertumbuhan neoklasik. Teori pertumbuhan endogen juga bertujuan untuk menghilangkan asumsi eksogen dari kemajuan teknologi. Romer (1986) mengembangkan teori pertumbuhan endogen dengan menyatakan bahwa pertumbuhan jangka panjang sangat ditentukan oleh akumulasi pengetahuan para pelaku ekonomi.

Romer mengembangkan teori pertumbuhan endogen yang bertumpu pada pentingnya sumber daya manusia sebagai kunci utama dalam perekonomian. Dalam model Romer, pertumbuhan jangka panjang sangat ditentukan oleh akumulasi pengetahuan 
para pelaku ekonomi. Tiga elemen utama dalam model Romer yaitu:

1. Adanya unsur eksternalitas, sebagai akibat kemajuan ilmu pengetahuan.

2. Adanya peningkatan skala hasil yang semakin meningkat (increasing return to scale), yang menyebabkan peningkatan spesialisasi dan pembagian kerja.

3. Semakin pendeknya waktu pemanfaatan ilmu pengetahuan, karena pesatnya perkembangan di sektor riset.

Secara umum model Romer (1986) dirumuskan sebagai berikut:

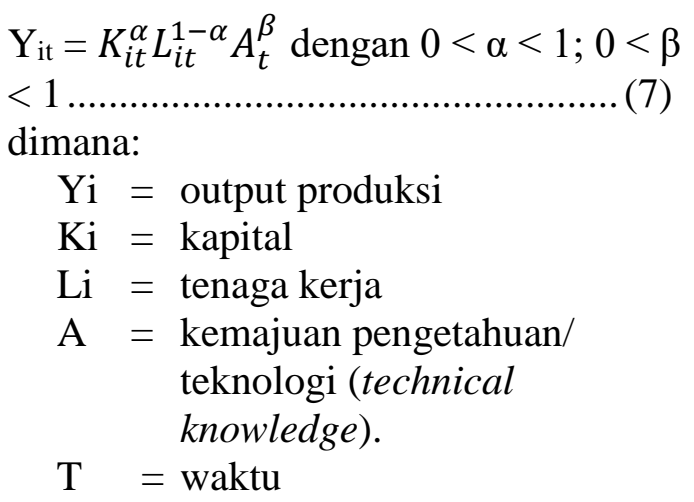

$\mathrm{Y}=\mathrm{AF}(\mathrm{L}, \mathrm{K})$

Dimana A adalah ukuran dari tingkat penggunaan teknologi atau disebut juga Total Faktor Productivity (TFP). Dengan demikian peningkatan produksi tidak hanya diakibatkan oleh peningkatan tenaga kerja dan kapital, tetapi juga oleh kenaikan TFP seperti pada persamaan no 6 .

\section{Konsep Pengukuran TFP}

Coelli et al. (2003) mengatakan bahwa metode pengukuran TFP dapat dikelompokkan kedalam dua pendekatan utama, yaitu metode konvensional (non-frontier) dan metode non-konvensional (frontier). Kemudian, baik dalam pendekatan konvensional mau-pun frontier dapat diklasifikasikan lagi menjadi metode parametrik dan nonparametrik. Metode parametrik memerlukan bentuk fungsi yang spesifik (fungsi produksi) dan menggunakan teknik ekonometrika dalam mengestimasi fungsi produksi, sehingga memerlukan asumsi-asumsi tertentu dalam estimasi-nya. Sedangkan metode nonparametrik tidak memaksakan bentuk fungsi yang spesifik ataupun asumsi-asumsi yang kaku dalam menghitung TFP.

Pendekatan konvensional mengasumsikan bahwa output dihasilkan secara efisien penuh (fully efficient), sedangkanpendekatan frontier memperbolehkan output dihasilkan secara tidak efisien penuh (not fully efficient), sehingga dalam memutuskan apakah akan menggunakan pendekatan konvensional atau pendekatan frontier tergantung apakah proses produksi perusahaan berjalan secara fully efficient ataukah not fully efficient.

Metode parametrik mengestimasi TFP melalui fungsi produksi seperti fungsi produksi Cobb-Douglas, Transcendental Logaritmic (Translog) dan Constant Elasticity Subtitution (CES). Prinsip dasar pengukuran TFP dengan mengguna-kan metode parametrik adalah dengan memanfaatkan nilai error dalam model regresi. Error dalam model regresi dapat mewakili pengaruh-pengaruh yang berasal dari luar atau yang tidak dapat dijelaskan oleh variabel penjelas yang digunakan dalam model. TFP menjelaskan porsi dari output yang 
tidak dapat dijelaskan oleh sejumlah input yang digunakan dalam produksi, maka pengukuran TFP identik dengan pengukuran error.

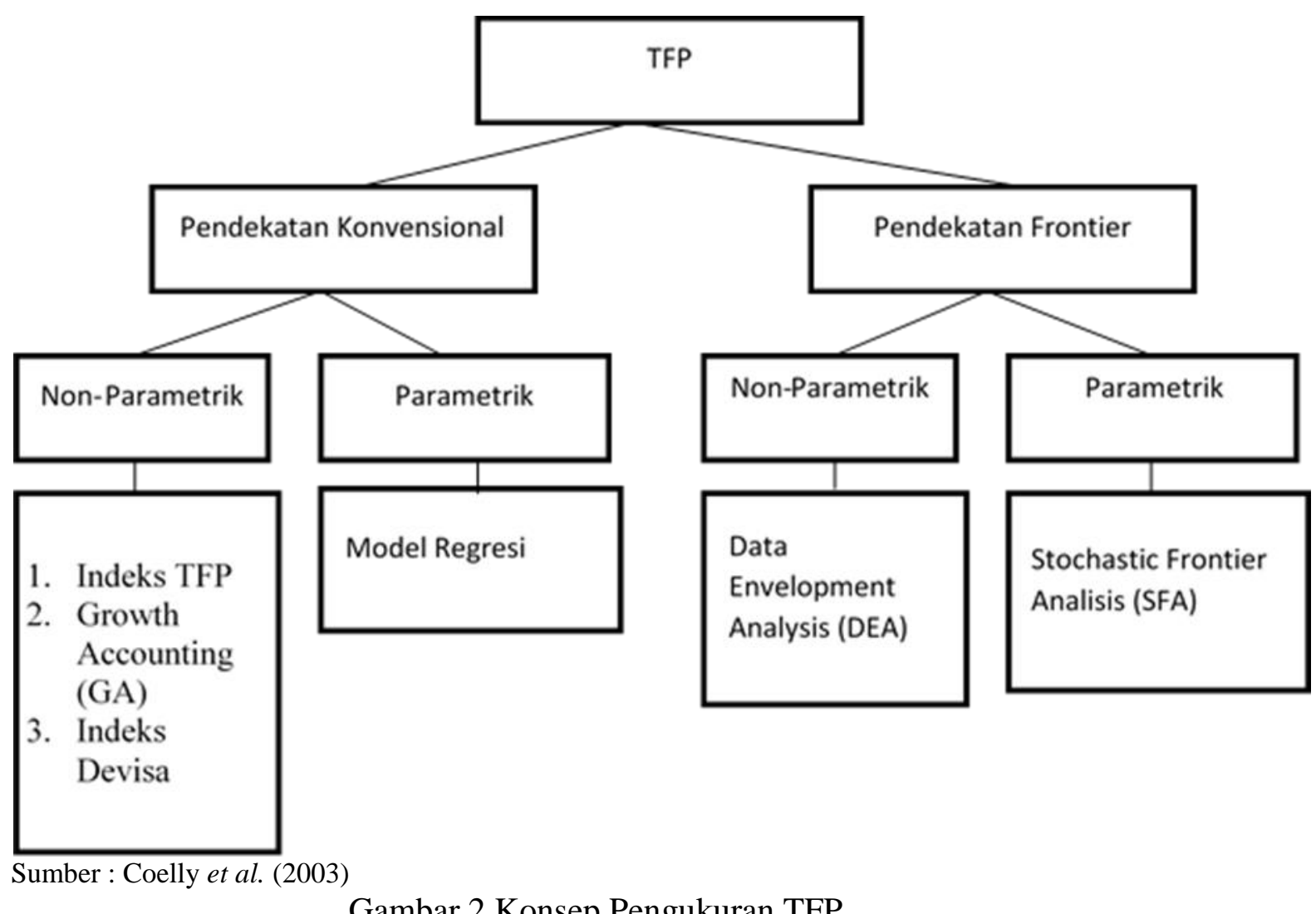

Gambar 2 Konsep Pengukuran TFP

Metode nonparametrik tidak diperlukan bentuk fungsi spesifik atau asumsi-asumsi statistik tertentu dalam mengukur TFP. TFP dihitung dengan cara merasiokan antara output dengan input agregat. Input agregat merupakan kombinasi linear dari $M$ input yang telah dikalikan dengan penimbangnya (weighting) masing-masing. Indeks kuantitas yang digunakan untuk output maupun input bisa bermacam-macam, seperti Indeks Laspeyres, Indeks Paasche, Indeks Fisher, Indeks Tornqvist. Dalam metode nonparametrik terdapat beberapa metode yang menggunakan konsep berbeda (bukan rasio output terhadap input) dan hanya bisa diterapkan untuk menghitung TFP Growth (TFPG), seperti metode Growth Accounting (GA), Indeks
Divisia, dan metode Data Envelopment Analysis (DEA) (Indeks Malmquist).

\section{Penelitian Terdahulu}

Penelitian Asghar (2011) yang menganalisis faktor-faktor makroekonomi yang menentukan TFP sektor pertanian di Negara Pakistan. Metode perhitungan TFP yang digunakan dalam penelitian ini adalah dengan menggunakan Tornqvist Thiel Index dari tahun 1970-2006. Permodelan yang digunakan dalam penelitian adalah Error Correction Model (ECM). Hasil penelitian menunjukkan bahwa sumber daya manusia, pembangunan infrastruktur dan kredit berhubungan positif dengan TFP pertanian. Keterbukaan ekonomi pertanian memiliki dampak yang positif dan 
signifikan terhadap produktivitas. Stabilitas makroekonomi mempengaruhi TFP secara negatif dan signifikan. Sementara pendapatan riil per kapita menunjukkan hubungan yang positif namun tidak signifikan dengan pertumbuhan TFP.

Supphanachart dan Warr mengkaji mengenai pengukuran dan faktor penentu TFP sektor pertanian di Negara Thailand. Metode yang digunakan untuk perhitungan TFP pertanian adalah dengan menggunakan metode growth accounting dari tahun 1970-2006. Ruang lingkup penelitian dibatasi untuk subsektor tanaman pangan dan peternakan. Permodelan yang digunakan untuk menentukan faktor-faktor yang memengaruhi TFP pertanian adalah Error Correction Model (ECM). Hasil menunjukkan bahwa TFP memeberikan kontribusi terhadap pertumbuhan ouput pertanian, baik tanaman pangan maupun peternakkan. Model ECM untuk subsektor tanaman pangan menunjukkan bahwa faktor-faktor yang menentukan TFP pertanian di subsektor pangan adalah kegiatan penelitian dan pengembangan pertanian, penyuluhan pertanian, dan infrastruktur. Sementara untuk peternakkan dipengaruhi oleh kegiatan penelitian dan pengembangan serta dummy flu burung.

Constantin et al. (2009) menggunakan dua metode dalam melihat pertumbuhan TFP pada sektor agribisnis di Brazil. Metode yang digunakan adalah model Cobb-Douglas dan Translog Stochastic Production Frontier. Variabel yang digunakan diantaranya produksi, luas panen, kredit pertanian dan agricultural lime stone. Hasil yang didapat terdapat trend positif pada TFP sektor pertanian Brazil. Dan teknologi merupakan faktor yang berkontri-busi besar terhadap TFP sektor pertanian Brazil.
Jajri dan Rahma (2009) melakukan penilitian mengenai produktivitas tenaga kerja, Kemajuan teknikal, skill tenaga kerja di Malaysia. Dengan menggunakan metode data envelopment analysis (DEA) ditemukan bahwa kemajuan teknikal efisiensi memberikan dampak positif pada produktivitas tenaga kerja sampai pada tahap perusahaan mampu melengkapi skill tenaga kerja dan terdapat hubungan positif antara skill dan produktivitas tenaga kerja.

Pada studi yang lain, Fuglie (2010) juga menemukan bahwa Indonesia mencapai tingkat pertumbuhan tahunan dalam produksi pertanian dari $3,6 \%$ selama periode 1961-2006 dengan menggunakan metode indeks Tornqvist-Thiel. Penelitian ini juga menghasilkan bahwa TFP di bidang pertanian dipercepat selama periode revolusi hijau (19681992) tapi kemudian pertumbuhan TFP mengalami stagnasi di tahun 1990-an dan tidak melanjutkan sampai pulih dari krisis Asia pada tahun 1997.

Coelli et al. (2003) menyebutkan bahwa teknologi dan pengeluaran riset pertanian adalah pendorong penting bagi TFP perubahan di Bangladesh Tanaman Pertanian. Sementara Li et al. (2015) ditemukan di Cina bahwa pertumbuhan produksi Pertanian di Cina di pengaruhi oleh kemajuan teknologi dan keuntungan effiiency. Kedua faktor tidak secara bersamaan mempengaruhi pertumbuhan produktivitas

Swastika (1996) menggunakan fungsi produksi frontier stochastic translog untuk mengukur perubahan teknologi dan perubahan efisiensi teknis serta kontribusinya terhadap pertumbuhan total faktor produktivitas pada padi sawah irigasi di Jawa Barat. Variabel penjelas yang disertakan dalam model ini adalah faktor input yang terdiri dari benih, pupuk, pestisida, 
tenaga kerja, dan penggunaan traktor, serta dummy waktu sebagai proksi dari perubahan teknologi tahun 1988 dan 1992. Pendugaan fungsi produksi frontier dilakukan dengan metode Maximum Likelihood Estimation (MLE). Hasil penelitian menunjukkan bahwa perubahan teknologi dari tahun 1980 sampai 1988 sebesar 42,72\%. Kenaikan TFP dari tahun 1980-1988 diduga disebabkan oleh perbaikan tingkat penerapan teknologi dari awal Insus sampai Supra Insus. Setelah Supra Insus, tidak ada lagi terobosan teknologi baru, baik dari segi kultur teknis maupun varietas baru yang berpotensi hasil melebihi varietas-varietas sebelumnya. Selain stagnasi teknologi, juga disebabkan penurunan genetik varietas-varietas yang ada, penurunan kualitas dan kesuburan tanah, dan serangan hama pada musim tanam 1992. Hasil penelitian ini juga menunjukkan bahwa perubahan teknologi selama periode analisis cenderung bias ke arah pengurangan benih dan tenaga kerja serta peningkatan pemakaian pupuk, pestisida, dan traktor.

Menggunakan SFA dengan fungsi produksi translog, Sharma et al. (2007) menguraikan pertumbuhan TFP untuk lebih rendah 48 negara bagian AS selama periode 1977-2000 dan menunjukkan bahwa pertumbuhan TFP terutama berasal dari kemajuan teknologi, sementara perbedaan dalam perubahan efisiensi menjelaskan lintas perbedaan -state di TFP. Minyak dan batubara memproduksi negara mengalami penurunan terbesar dalam efisiensi, sementara mereka dengan sektor keuangan yang lebih besar mengalami kenaikan terbesar. Juga, modal manusia, urbanisasi, dan saham non-pertanian dan keuangan sektor yang positif terkait dengan efisiensi. Jerzmanowski (2007) juga menemukan bahwa pertumbuhan TFP di AS antara tahun 1960 dan 1995 adalah sepenuhnya karena perkembangan teknologi saat perubahan efisiensi rata-rata adalah nol.

Dengan menggunakan metode yang sama, Aswicahyono dan Hill (2002) menghitung pertumbuhan TFP pada 28 sektor industri manufaktur selama periode 1975-1993 dengan ratarata pertumbuhan TFP sebesar 2,3\%. Aswicahyono (1998) menemukan nilai TFP growth mencapai 5,5 samapi 6\% pada tahun 1984-1998 dan 1989 dan 1993 dari sebelumnya bernilai negatif 4,9 percent antara tahun 1981 dan 1983. Hasil lainnya mengindikasikan adanya penurunan nilai TFP pada masa krisis di tahun 1997. Vial (2006) menunjukkan pertumbuhan TFP sebesar 1,08\% tahun 1991 samapai 1996, dimana terjadi penurunan yang cukup dalam dibandingkan tahun 1986-1990 yang memiliki pertumbuhan TFP sebesar $8,93 \%$.

Sirait (2007) dalam disertasinya telah mencoba melihat total faktor produktifitas industri manufaktur usaha menengah dan usaha besar dengan dua pendekatan yaitu menggunakan regresi berdasarkan teori pertumbuhan solow dan juga pendekatan stochastic production frontier. Dari hasil penilitian di temukan bahwa pertumbuhan TFP baik untuk usaha menengah maupun usaha besar banyak didorong oleh perubahan teknologi. Namun di beberapa sektor ditemukan bahwa perubahan efisiensi berpengaruh terhadap pertumbuhan TFP yang menunjukkan bahwa perhatian terhadap perbaikan kualitas faktor produksi juga harus dilakukan.

Jung dan Pyo (2008) menggunakan metode stochastic frontier dalam melihat perkembangan TFP pada sektor jasa dan industri dengan menggunakan data dari berbagai perusahaan pada tahun 2005-2007. Variabel yang digunakan adalah capital, tenaga kerja 
dan bahan baku. Dari hasil penelitian ditemukan bahwa perkembangan TFP di sektor jasa bernilai negatif sedangkan sektor lainnya bernilai positif. Efisiensi teknis berkontribusi paling rendah diantara teknologi dan skala usaha dalam pertumbuhan TFP.

Constantin et al. (2009) menggunakan dua metode dalam melihat pertumbuhan TFP pada sektor agribisnis di Brazil. Metode yang digunakan adalah model Cobb-Douglas dan Translog Stochastic Production Frontier. Variabel yang digunakan diantaranya produksi, luas panen, kredit pertanian dan agricultural lime stone. Hasil yang didapat terdapat trend positif pada TFP sektor pertanian brazil. Dan teknologi merupakan faktor yang berkontribusi besar terhadap TFP sektor pertanian Brazil.

Pada studi yang lain, Fuglie (2010) juga menemukan bahwa Indonesia mencapai tingkat pertumbuhan tahunan dalam produksi pertanian dari $3,6 \%$ selama periode 1961-2006 dengan menggunakan metode Indeks Tornqvist-Thiel. Penelitian ini juga menghasilkan bahwa TFP di bidang pertanian dipercepat selama periode revolusi hijau (19681992) tapi kemudian pertumbuhan TFP mengalami stagnasi di tahun 1990-an dan tidak melanjutkan sampai pulih dari krisis Asia pada tahun 1997.

\section{METODE PENELITIAN}

\section{Jenis dan Sumber Data}

Data yang digunakan dalam penelitian ini adalah data sekunder tahunan dalam bentuk time series (deret waktu) selama periode 2002-2013. Data tersebut diperoleh dari informasi statistik yang dimiliki oleh Badan Pusat Statistik (BPS). Terdapat 15 industri yang menjadi cakupan penelitian yaitu industri makanan dan minuman, tembakau, tekstil, pakaian jadi, kulit dan barang dari kulit, kayu, perebitan, percetakan dan reproduksi media rekaman, kimia, karet, galian, logam basic, logam, mesin listrik, kedokteran, dan furniture.

Tabel 1 Data dan sumber data penelitian

\begin{tabular}{|c|c|c|}
\hline No & Jenis Data & Sumber Data \\
\hline \multirow[t]{2}{*}{1} & Total & Statistik Industri \\
\hline & Produksi & Tahun 2002-2013 \\
\hline \multirow[t]{2}{*}{2} & Kapital & Statistik Industri \\
\hline & & Tahun 2002-2013 \\
\hline 3 & Tenaga Kerja & $\begin{array}{l}\text { Statistik Industri } \\
\text { Tahun 2002-2013 }\end{array}$ \\
\hline \multirow[t]{2}{*}{4} & Biaya Bahan & Statistik Industri \\
\hline & $\begin{array}{l}\text { Baku dan } \\
\text { Energi }\end{array}$ & Tahun 2002-2013 \\
\hline
\end{tabular}

\section{Definisi Operasional}

Berikut ini definisi mengenai data yang digunakan dalam penelitian ini

1. Total produksi adalah nilai produksi yang dihasilkan oleh seluruh perusahaan yang berada pada sektor yang dianalisis dalam satuan juta rupiah

2. Kapital adalah jumlah taksiran modal yang diperkirakan yang ada untuk memenuhi proses produksi, taksiran modal terdiri dari gedung, mesinmesin dan peralatan lainnya yang sudah tergabung dalam data statistic industri ISIC rev 3 dalam satuan juta rupiah

3. Tenaga kerja adalah jumlah tenaga kerja yang terdapat pada sektor yang dianalisis dalam satuan orang kerja

4. Biaya bahan baku dan energi adalah biaya yang dikeluarkan untuk sproses produksi dalam satu tahun dalam satuan juta rupiah. 


\section{Model TFP menggunakan pendekatan translog stocastic frontier analysis}

Penggunaan fungsi produksi stochastic dimaksudkan unduk mengetahui sumber-sumber pertumbuhan. Sumber-sumber pertumbuhan diantaranya efisiensi teknis, teknologi dan skala usaha. Sedangkan penggunaan model translog untuk mendekteksi skala usaha yang bersifat non constant returm to scale. Secara garis besar model penelitian translog stochastic frontier analysis baik pada sector manufaktur dapat ditulis sebagai berikut Sirait (2007) dan Modjo (2006)

$$
\begin{aligned}
& \text { In } y_{i t}=\beta_{0}+\beta_{1} \operatorname{In} l_{i t}+\beta_{\mathrm{k}} \operatorname{In} k_{i t}+\beta_{\mathrm{m}} \operatorname{In} m_{i t} \\
& +\beta_{\mathrm{t}} t+\frac{1}{2} \beta_{\mathrm{it}}\left(\operatorname{In} l_{i t}\right)^{2}+\frac{1}{2} \beta_{\mathrm{kk}}(\ln \\
& \left.k_{i t}\right)^{2}+\frac{1}{2} \beta_{\mathrm{mm}}\left(\ln m_{i t}\right)^{2}+\frac{1}{2} \beta_{t} t^{2}+\beta_{\mathrm{lk}} \\
& \ln l_{i t} \ln k_{i t}+\beta_{\operatorname{lm}} \ln l_{i t} \ln m_{i t}+\beta_{\mathrm{km}} \\
& \ln k_{i t} \ln m_{i t}+\beta_{\mathrm{kt}} t \ln k_{i t}+\beta_{\mathrm{mt}} t \\
& \ln m_{i t}+\beta_{\mathrm{lt}} t \ln l_{\text {it }}+\mathrm{v}_{\mathrm{it}}- \\
& \mathbf{u}_{\text {it }}
\end{aligned}
$$

Dimana:

$$
\begin{aligned}
\mathrm{Y}_{\text {it }}= & \text { Nilai Produksi } \\
\text { Lit }= & \text { Jumlah Tenaga Kerja (Jiwa) } \\
\mathrm{Kit}= & \text { Nilai Taksiran Kapital (ribu) } \\
\mathrm{Mit}= & \text { Nilai Bahan Baku dan energi } \\
& \text { (ribu) } \\
\mathrm{T}= & \text { Peubah waktu sebagai proksi } \\
& \text { teknologi endogenus }
\end{aligned}
$$

Dari persamaan 14 maka dapat dihitung pertumbuhan teknologi yaitu

$\mathbf{T C}=\beta_{\mathrm{t}}+\beta_{\mathrm{tt}} \mathrm{t}+\beta_{\mathrm{It}} \ln \mathrm{L}_{\mathrm{it}}+\beta_{\mathrm{kt}} \ln \mathrm{K}_{\mathrm{it}}+$

$\beta_{M t} \ln M_{i t}$

Dari persemaan diatas akan didaptakan efisiensi teknis, skala usaha, dan perubahan teknologi yang akan digunakan untuk mendapatkan pertumbuhan TFP. Model pertumbuhan TFP mengacu pada Lovell (2000) dimana dapat dirumuskan sebagai berikut:

$$
\begin{aligned}
& T \dot{F} P=T C-\frac{\delta u}{\delta t}+(R T S- \\
& \text { 1) } \sum_{j} \lambda_{j} \dot{x}_{j}
\end{aligned}
$$

Dimana :

$T \dot{F} P=$ pertumbuhan TFP

$\mathrm{TC}=$ perubahan teknologi

$\left(-\frac{\delta u}{\delta t}\right)=$ perubahan efisiensi tekniks $(R T S-1) \sum_{j} \lambda_{j} \dot{x}_{j}=$ perubahan skala usaha

Dalam menghitung skala usaha diperlukan nilai elastisitas dari masingmasing input :

1) Elastisitas output tenaga kerja

$$
\varepsilon_{y / l}=\frac{d \ln Y}{d \operatorname{Ln} L}
$$

2) Elastisitas output kapital

$$
\varepsilon_{y / l}=\frac{d \ln Y}{d \operatorname{Ln} k}
$$

3) Elastisitas output bahan baku

$$
\varepsilon_{y / l}=\frac{d \ln Y}{d \operatorname{Ln} M}
$$

\section{Model TFP pendekatan Fungsi Produksi Cobb-Douglas}

Berdasarakan persamaan fungsi Cobb-Douglas pada persamaan 12 dan mengikuti landasan dari Asian Productivity Organization (2015) maka dalam penelitian ini input yang digunakan adalah biaya bahan baku (B), jumlah tenaga kerja (L), sewa modal (SM), sehingga persamaan 6 menjadi:

$\mathrm{LnY}_{\text {it }}=\beta_{0}+\beta \mathrm{LnL}_{\mathrm{it}}+\gamma \mathrm{LnK}_{\mathrm{it}}+\alpha$

$\mathrm{LnM}_{\mathrm{it}}+\mathrm{TFP}_{\mathrm{it}}$

dimana:

$$
\begin{aligned}
\text { TFP }_{i t}= & \text { Pertumbuhan Total Faktor } \\
& \text { Productivity }(\%) \\
Y_{i t}= & \text { Nilai Produksi } \\
\text { Lit }= & \text { Jumlah Tenaga Kerja (jiwa) } \\
\text { Kit }= & \text { Nilai Taksiran Kapital (juta) } \\
\text { Mit }= & \text { Nilai Bahan Baku dan } \\
& \text { energi (juta) }
\end{aligned}
$$




\section{Metode Panel Data}

Terdapat beberapa macam model ekonometrika metode data panel yaitu pooled least square (PLS), fixed effect model (FEM), dan random effect model (REM). Dalam menentukan apakah model kita merupakan PLS, FEM ataupun REM. Maka terdapat beberapa uji yang harus dilakukan yaitu uji Chow Test untuk menentukan apakah FEM atau PLS dan Uji Hausman untuk menentukan apakah REM atau FEM.

\section{Chow Test}

Chow Test adalah pengujian untuk memilih model yang akan digunakan antara model Pooled Least Square atau Fixed Effect. Dalam pengujian ini hipotesis yang digunakan sebagai berikut:

$\mathrm{H}_{0}$ : Model Pooled Least Square

$\mathrm{H}_{1}$ : Model Fixed Effect

Dasar penolakan terhadap hipotesa nol $\left(\mathrm{H}_{0}\right)$ adalah dengan menggunakan F- Statistik seperti yang dirumuskan oleh Chow:

$$
\mathrm{F}(\mathrm{N}-1, \mathrm{NT}-\mathrm{N}-\mathrm{K})=\frac{\frac{(\mathrm{ESS} 1-\mathrm{ESS} 2)}{\mathrm{N}-1}}{\frac{\mathrm{ESS} 2}{\mathrm{NT}-\mathrm{N}-\mathrm{K}}}
$$

Dimana:

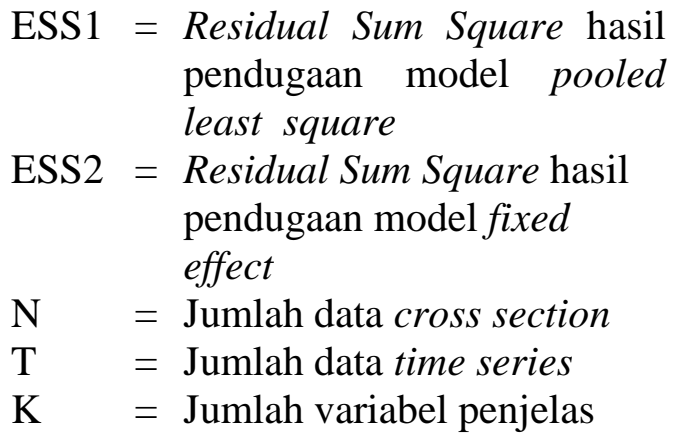

Statistik Chow Test mengikuti distribusi F-statistik dengan derajat bebas (N-1, NT-N-K). jika nilai statistik Chow (F-Stat) hasil pengujian lebih besar dari F-tabel maka cukup bukti untuk melakukan penolakan hipotesa nol sehingga model yang digunakan adalah model fixed effect, dan begitu juga sebaliknya.

\section{Haussman Test}

Haussman Test adalah pengujian statistik sebagai dasar pertimbangan untuk memilih model terbaik antara model fixed effect atau model random effect. Haussman Test dilakukan dengan hipotesa sebagai berikut:

\section{$\mathrm{H}_{0}$ : Model Random Effect \\ $\mathrm{H}_{1}$ : Model Fixed Effect}

Sebagai dasar penolakan H0, maka digunakan statistic Hausman dan membandingkan dengan Chi-Square. Statistik Haussman dirumuskan dengan:

$$
\mathrm{M}=\mathrm{m}=\beta-\mathrm{b}(\mathrm{Mo}-\mathrm{M} 1)-\beta-\mathrm{b}-\chi^{2}
$$

Dimana $\beta$ adalah vektor untuk variabel fixed effect, $b$ adalah vektor statistik variabel random effect, M0 adalah matriks kovarians untuk dugaan random effect model. Jika nilai $\mathrm{m}$ hasil pengujian lebih besar dari $\chi^{2}$-Tabel, maka sudah cukup bukti untuk melakukan penolakan terhadap hipotesa nol sehingga model yang digunakan adalah fixed effect model, dan begitu juga sebaliknya.

\section{HASIL DAN PEMBAHASAN}

\section{Gambaran Umum}

Sektor industri pengolahan Indonesia sebagian besar mengalami peningkatan dari tahun 2002 hingga tahun 2013. Sektor makanan dan minuman memegang peranan penting dalam sindustri pengolahan di Indonesia. Hingga tahun 2013 industri makanan dan minuman mencapai 926 triliun rupiah meningkat dari tahun 
hamper Sembilan kali dari tahun 2002 yang hanya 133 triliun rupiah. Sektor kedua yang cukup tinggi yaitu kimia dan barang-barang dari bahan kimia dimana nilai outputnya pada tahun 2013 sebanyak 479 triliun atau setara 5 kalinya nilai produksi pada tahun 2002.

Sebagian besar industri
pengolahan di Indonesia mengalami peningkatan namun terdapat beberapa industri yang nilainya mengalami penurunan dari tahun 2002 hingga tahun 2013 yaitu industri barang-barang dari logam, Dimana pada tahun 2002 industri ini mampu mengahasilkan output sebesar 102 triliun namun pada tahun 2013 hanya mencapai 96 triliun rupiah. Nilai terendah output yang dihasilkan pada industri barang-barang logam pada tahun 2005 yang hanya mencapai 24 triliun rupiah.

Tabel 2 Perkembangan Output Produksi 15 Sektor Industri Pengolahan Non Migas Tahun 2002, 2005, 2008, 2011-2013 dalam Juta Rupiah

\begin{tabular}{lrrrrrr}
\hline Sektor & $\mathbf{2 0 0 2}$ & $\mathbf{2 0 0 5}$ & $\mathbf{2 0 0 8}$ & $\mathbf{2 0 1 1}$ & $\mathbf{2 0 1 2}$ & $\mathbf{2 0 1 3}$ \\
\hline Makanan dan & & & & & & \\
minuman & 133.543 & 204.053 & 457.008 & 658.497 & 736.078 & 926.716 \\
Tembakau & 54.631 & 59.377 & 124.414 & 121.284 & 161.073 & 198.783 \\
Tekstil & 68.130 & 93.029 & 102.965 & 161.089 & 148.205 & 178.959 \\
Pakaian jadi & 28.166 & 36.806 & 43.517 & 55.900 & 64.011 & 87.051 \\
Kulit dan barang & & & & & & \\
dari kulit & 23.775 & 22.872 & 35.068 & 50.096 & 68.463 & 58.094 \\
Kayu & 41.781 & 44.755 & 45.248 & 39.566 & 50.440 & 49.786 \\
Penerbitan, & & & & & & \\
percetakan dan & & & & & & \\
reproduksi media & & & & & & \\
rekaman & 6.272 & 14.156 & 13.959 & 24.064 & 17.302 & 17.190 \\
Kimia & 9.492 & 110.065 & 266.230 & 359.715 & 368.265 & 479.335 \\
Karet & 41.909 & 97.521 & 158.372 & 284.834 & 234.534 & 206.582 \\
Galian & 23.815 & 37.284 & 53.369 & 65.051 & 94.864 & 82.158 \\
Logam Basic & 43.278 & 79.920 & 112.776 & 90.784 & 119.280 & 132.219 \\
Logam & 102.004 & 24.192 & 49.619 & 79.458 & 115.854 & 96.461 \\
Mesin Listrik & 14.746 & 25.534 & 51.427 & 60.091 & 96.204 & 108.811 \\
Kedokteran & 1.154 & 2.382 & 3.236 & 2.583 & 4.461 & 9.188 \\
Furniture & 17.128 & 19.970 & 39.647 & 45.376 & 41.712 & 49.338 \\
\hline Sumber: Statistik & & & & & & \\
& & & & & & \\
\end{tabular}

Sumber: Statistik Industri (2002-2013)

Selain tingginya output industri pengolahan juga berperan dalam penyerapan tenaga kerja. Lebih dari 4,9 juta tenaga kerja Indonesia terserap pada industri pegolahan. Sektor yang paling banyak menyerap tenaga kerja di Indonesia yaitu makanan dan minuman dimana pada tahun 2013 lebih dari 900 ribu tenaga kerja terserap pada sektor ini. Kemudian sektor yang memberikan kontribusi terbesar untuk tenaga kerja yaitu tekstil (528 ribu) dan pakaian jadi
(514 ribu). Meskipun tekstil menjadi terbesar namun jumlah tenaga kerja pada industri tekstil semakin menurun. Padahal dari sisi output nilai industri tekstil terus meningkat. Hal ini berarti adanya peningkatan penggunaan mesin pada industri tekstil sehingga penggunaan tenaga kerja pada industri ini semakin berkurang dari tahun 2002 hingga 2013. Dari sisi input sebagian besar input industri pengolahan di Indonesia berasal dari bahan baku dan 
modal di Indonesia. Pada tahun 2008 dan 2009 terjadi pengurangan proposi modal dibandingkan dengan tahun 2000 hingga tahun 2007. Hal ini disebabkan terjadinya krisis global pada tahun tersebut yang menyebabkan banyaknya modal yang keluar dari Indonesia.
Sehingga proporsi bahan baku melebih dari $50 \%$. Seiring dengan perbaikan ekonomi pada tahun 2010 modal kembali masuk ke Indonesia yang menyebabkan proporsi input industri pengolahan di Indonesia kembali naik hingga tahun 2012.

Tabel 3 Perkembangan Tenaga Kerja Produksi 15 Sektor Industri Pengolahan Non Migas Tahun 2002, 2005, 2008, 2011-2013

\begin{tabular}{lrrrrrr}
\hline Sektor & $\mathbf{2 0 0 2}$ & $\mathbf{2 0 0 5}$ & $\mathbf{2 0 0 8}$ & $\mathbf{2 0 1 1}$ & $\mathbf{2 0 1 2}$ & $\mathbf{2 0 1 3}$ \\
\hline Makanan dan & 625.168 & 636.625 & 721.457 & 780.944 & 925.318 & 946.188 \\
minuman & 265.378 & 272.343 & 346.042 & 304.103 & 323.561 & 361.927 \\
Tembakau & 579.811 & 567.042 & 484.732 & 534.515 & 541.808 & 528.677 \\
Tekstil & 473.336 & 451.975 & 495.518 & 459.960 & 534.490 & 514.546 \\
Pakaian.jadi & & & & & & \\
Kulit dan barang & 263.796 & 208.723 & 219.792 & 247.362 & 256.307 & 266.609 \\
dari kulit & & & & & & \\
Kayu & 400.008 & 312.193 & 241.226 & 211.135 & 223.040 & 227.328 \\
Penerbitan, & & & & & & \\
percetakan dan & 56.223 & 49.371 & 59.065 & 45.992 & 52.050 & 51.154 \\
reproduksi media & & & & & & \\
rekaman & & & & & \\
Kimia & 199.317 & 208.621 & 199.990 & 233.516 & 250.418 & 266.874 \\
Karet & 355.332 & 334.345 & 360.181 & 358.761 & 354.896 & 366.740 \\
Galian & 170.048 & 165.056 & 176.459 & 174.580 & 192.514 & 181.398 \\
Logam Basic & 59.228 & 56.411 & 64.099 & 64.641 & 60.418 & 73.206 \\
Logam & 119.195 & 123.349 & 147.330 & 152.986 & 159.850 & 169.977 \\
Mesin Listrik & 72.174 & 81.251 & 77.094 & 89.972 & 94.576 & 93.244 \\
Kedokteran & 14.832 & 17.521 & 25.071 & 15.288 & 16.974 & 17.568 \\
Furniture & 274.928 & 260.766 & 313.656 & 335.739 & 349.219 & 314.080 \\
\hline Sir Stik
\end{tabular}

Sumber: Statistik Industri 2002-2013

\section{Hasil Estimasi Persamaan Produksi Menggunaka Stochastic Frontier Analysis}

Hasil estimasi menggunakan nilai stochastic frontier analysis dengan pendekatan model translog secara garis besar dapat dikatakan valid dikarenakan nilai sigma kuadrat signifikan dan lebih kecil dari nilai gamma. Hal ini menunjukan bahwa nilai eror pada ragam masih berada dalam batas kewajaran. Hasil estimasi menunjukan bahwa variabel biaya bahan baku berpengaruh signifikan terhadap produksi yang dilihat dari nilai t-ratio lebih besar dari 1,6. Sedangakan tenaga kerja, kapital dan trend waktu tidak signifikan terhadap produksi. Setiap peningkatan bahan baku sebesar $1 \%$ akan meningkatkan produksi sebesar $0,52 \%$. Secara implisit, temuan ini memberikan bukti bahwa sektor industri menengah dan besar sangat dipengaruhi oleh penggunaan bahan baku. Sehingga upaya untuk meningkatkan kemampuan produksi industri dapat dilakukan dengan peningkatan penggunaan bahan baku. 
Tabel 4 Hasil Estimasi Stochastic Frontier Analysis Pada Industri Manufaktur

\begin{tabular}{lrrr}
\hline Variabel & $\begin{array}{r}\text { Koefisien } \\
\text { Variabel }\end{array}$ & standard-error & t-ratio \\
\hline C & $10,1633^{*}$ & 2,5524 & 3,9818 \\
Kapital & 0,0260 & 0,3043 & 0,0855 \\
Tenaga_kerja & $0,1037^{*}$ & 0,2420 & 4,2840 \\
Biaya Bahan Baku & $0,5245^{*}$ & 0,3126 & 1,9781 \\
Time & $-0,0196$ & 0,0792 & $-0,2479$ \\
$0,5^{*}$ Kapital $^{2}$ & $-0,0060$ & 0,0384 & $-0,1558$ \\
$0,5^{*}$ Tenaga_Kerja & 0,0022 & 0,0246 & 0,0897 \\
$0,5^{*}$ Biaya_Bahan_Baku & $0,0210^{*}$ & 0,0365 & 5,7700 \\
$0,5^{*}$ Time & 0,0020 & 0,0030 & 0,6623 \\
Kapital*TenagaKerja & 0,0083 & 0,0202 & 0,4118 \\
Tenaga Kerja*Biaya Bahan & $-0,0130^{*}$ & 0,0179 & $-7,2530$ \\
Baku & $-0,0050$ & 0,0304 & $-0,1655$ \\
Kapital*Biaya Bahan Baku & 0,0060 & 0,0051 & 1,1631 \\
Kapital*Time & 0,0010 & 0,0038 & 0,2660 \\
Tenaga Kerja*Time & $-0,0046$ & 0,0042 & $-1,0954$ \\
Biaya Bahan Baku*Time & 0,0144 & 0,0016 & 8,7958 \\
sigma-squared & 0,9999 & 0,5715 & 1,7498 \\
Gamma & & & 127,09 \\
\hline Log-Likelihood MLE & & & 42,38 \\
Log-Likelihood OLS & & & 169,41 \\
\hline LR & & &
\end{tabular}

Keterangan: * Signifikan pada 5\%

Sumber : Hasil Olahan Frontier 4,1

Peubah teknologi yang diproksi dengan waktu tidak signifikan terhadap produksi yang menggambarkan hingga saat ini penggunaan teknologi belum secara penuh dimanfaatkan oleh industri untuk digunakan dalam proses produksi. Belum banyaknya paten yang digunakan dalam proses industri juga membuat teknologi yang telah ada tidak berpengaruh terhadap proses produksi. Tenaga kerja yang belum memiliki pendidikan yang tinggi juga membuat teknologi tidak berpengaruh signifikan terhadap proses produksi yang dibuktikan dengan tidak signifikannya antara tenaga kerja dan variabel waktu.

\section{Efisiensi Teknis Pengolahan Indonesia}

Efisiensi teknis merupakan suatu ukuran untuk mengukur tingkat efisiensi antara sector. Nilai efisiensi antara 0-1 dimana semakin tinggi tingkat efisiensinya maka akan mendekati nilai 1.

Dari hasil estimasi didapatkan bahwa sebagian besar industri pengolahan di Indonesia mengalami peningkatan efisiensi kecuali pada beberapa industri pengolahan kayu. Penurunan efisiensi kayu disebabkan karena menurunya output akibat dari dibatasinya penebangan kayu dan ketatnya undang-undang lingkungan.

Industri yang memiliki nilai efisiensi tertinggi yaitu industri 
makanan, diikuti oleh industri memang merupakan industri utama di tembakau, dan industri tekstil. Ketiga Indonesia sehingga nilai efisiensi industri tersebut tidak berubah teknisnya lebih tinggi dibandingkan urutannya dari tahun 2003 hingga tahun 2013. Keempat industri tersebut dengan industri lainnya.

Tabel 5 Rata-rata Efisiensi Teknis Industri Pengolahan Indonesia pada Tahun 2002 2013

\begin{tabular}{lccc}
\hline \multicolumn{1}{c}{ Industri } & $\mathbf{2 0 0 2 - 2 0 0 5}$ & $\mathbf{2 0 0 6 - 2 0 0 9}$ & $\mathbf{2 0 1 0 - 2 0 1 3}$ \\
\hline $\begin{array}{l}\text { Makanan dan } \\
\text { minuman }\end{array}$ & 0,6411 & 0,8090 & 0,9188 \\
Tembakau & 0,7662 & 0,7086 & 0,7358 \\
Tekstil & 0,5173 & 0,5719 & 0,5833 \\
Pakaian jadi & 0,3996 & 0,4947 & 0,5220 \\
Kulit dan barang dari & & & \\
kulit & 0,3438 & 0,3618 & 0,4128 \\
Kayu & 0,4454 & 0,4126 & 0,3653 \\
Penerbitan, percetakan & & & \\
dan reproduksi media & & & \\
rekaman & 0,2712 & 0,3153 & 0,3202 \\
Kimia & 0,6048 & 0,7784 & 0,7653 \\
Karet & 0,4381 & 0,5454 & 0,6117 \\
Galian & 0,5278 & 0,5414 & 0,5682 \\
Logam Basic & 0,4214 & 0,4947 & 0,5164 \\
Logam & 0,3644 & 0,4226 & 0,4474 \\
Mesin Listrik & 0,3172 & 0,4149 & 0,5457 \\
Kedokteran & 0,1353 & 0,1983 & 0,1892 \\
Furniture & 0,3240 & 0,3929 & 0,3917 \\
\hline Sumber: Hasil Olahan & & &
\end{tabular}

Pertumbuhan Teknologi Industri Pengolahan Indonesia

Pada model stochastic frontier analysis pertumbuhan teknologi didefiniskan sebagai perubahan output akibat dari perubahan waktu atau turunan dari output terhadap waktu. Dapat dilihat pada gambar bahwa pertumbuhan teknologi pada semua industri di Indonesia mengalami peningkatan. Namun meskipun mengalami peningkatan nilai peningkatan tersebut relatif kecil dari pada tahun 2003 sebesar 0,01-0,02 hanya menjadi 0,03-0,05 pada tahun 2013. 


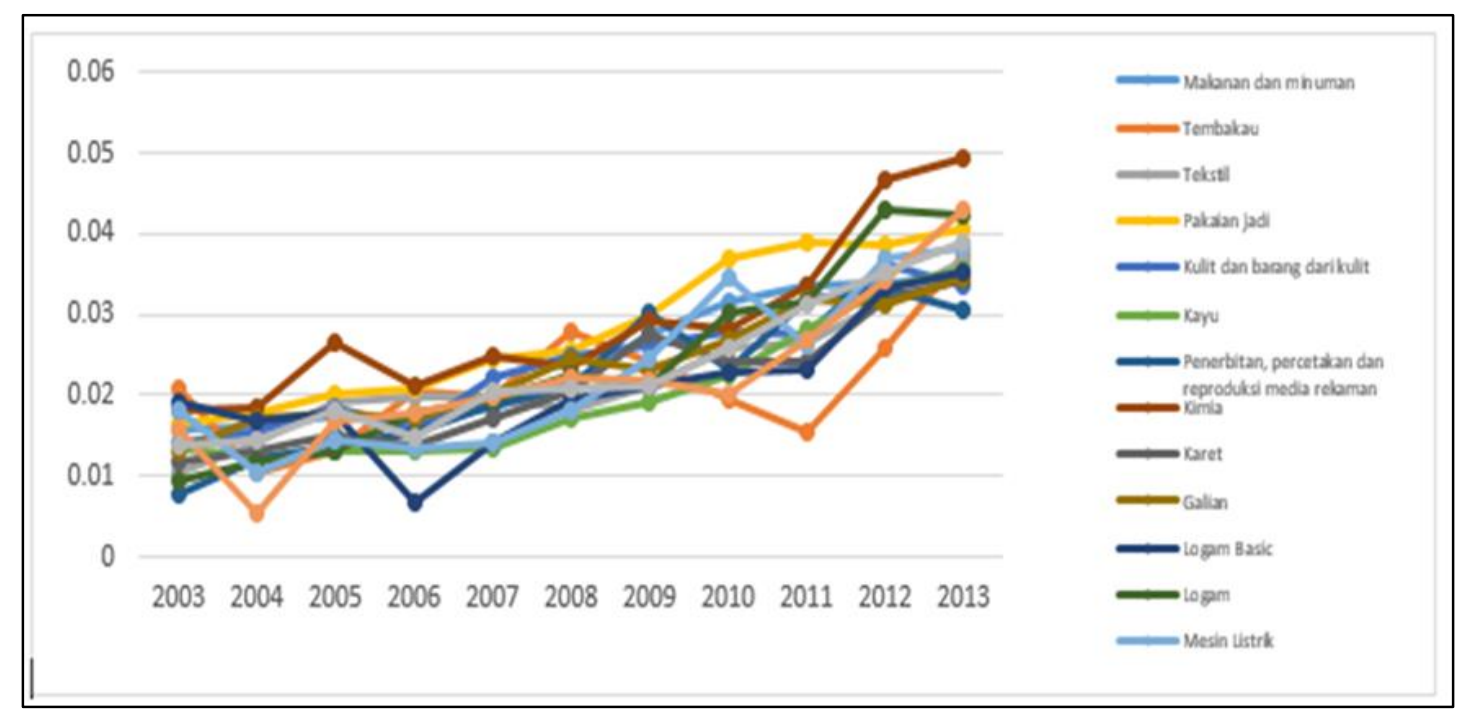

Gambar 4. Pertumbuhan Teknologi Industri Manufaktur di Indonesia Tahun 2003-2013

Rendahnya tingkat pertumbuhan teknologi disebabkan bukan karena rendahnya pertumbuhan teknologi di Indonesia karena berdasarkan jumlah paten di Indonesia terus mengalami peningkatan. Rendahnya pertumbuhan teknologi disebabkan oleh kurangya kualitas sumberdaya manusia yang belum dapat memanfaatkan teknologi secara menyeluruh. Hal ini berdampak pada hasil estimasi model produksi dimana variabel waktu tidak berpengaruh signifikan terhadap model produksi.

\section{Pertumbuhan Total Faktor Produktivitas Industri Manufaktur Indonesia}

Pertumbuhan total faktor produktifitas menggunakan pendekatan stochastic frontier analysis terdiri dari tiga komponen yaitu pertumbuhan efisiensi teknis, perubahan skala usaha, dan pertumbuhan teknologi. Tabel 6 merupakan tabel yang menyakian pertumbuhan total faktor produktivitas pada beberapa industri pengolahan di Indonesia.

Industri yang memiliki total faktor produktivitas tertinggi pada tahun 20032005 adalah indutri kedokteran $(15,49)$ diikuti oleh industri karet $(8,73)$, penerbitan $(8,36)$, pakaian jadi $(6,70)$, dan makanan dan minuman $(6,14)$. Industri terendah yaitu indutri kayu yang memiliki nilai total faktor produktivitas yang negative yaitu $-4,05$. Sulitnya teknologi seta pengembangan usaha akibat dari pembatasan usaha kayu hutan membuat industri ini menjadi memiliki nilai totak faktor produktivitas yang rendah.

Pada periode tahun 2006-2009 sebagian besar industri mengalami penurunan pertumbuhan total faktor produktivitas seperti industri makanan dan minumnan, tekstil, pakaian jadi, tembakau, penerbitan, kimia, karet, kedokteran dan furniture. Bahkan beberapa industri tersebut mengalami nilai produktivitas yang negatif yaitu tembakau dan tekstil. Periode krisis membuat tingkat produksi mengalami penurunan sehingga skala usaha pun mengalami penurunan yang menjadikan pertumbuhan total faktor produktivitas menurun.

Periode pasca krisis tahun 2010 hingga tahun 2013 mengalami perbaikan dilihat dari nilai pertumbuhan total faktor produktivitas mengalami peningkatan pada sebagian besar 
industri pengolahan di Indonesia kecuali industri Penerbitan, karet dan logam. Berkembanya internet membuat industri penerbitan mengalami penurunan sehingga skala usaha menjadi lebih kecil dibandingkan dengan perode 2003-2005. Hal ini menjadikan industri ini kian terpuruk sehingga nila total faktor produktivitas mengalami penurunan. Begitupun dengan karet maraknya bahan karet sintetis membuat industri karet kian menurun dan menyebabkan terjadinya penurunan total faktor produktivitas.

Tabel 6 Pertumbuhan Total Faktor Produktivitas Industri Pengolahan Indonesia Pendekatan SFA (\%)

\begin{tabular}{lccc}
\hline Industri & $\mathbf{2 0 0 2 - 2 0 0 5}$ & $\mathbf{2 0 0 6 - 2 0 0 9}$ & $\mathbf{2 0 1 0 - 2 0 1 3}$ \\
\hline Makanan dan minuman & 6,1488 & 3,8328 & 6,9594 \\
Tembakau & 2,3133 & $-2,3487$ & 8,3045 \\
Tekstil & 4,0902 & $-0,8581$ & 5,7017 \\
Pakaian jadi & 6,7031 & 3,2191 & 4,1619 \\
Kulit dan barang dari kulit & 1,8352 & 2,4116 & 7,8480 \\
Kayu & $-4,0528$ & $-2,1151$ & 1,7648 \\
Penerbitan, percetakan dan reproduksi & 8,3627 & 8,0699 & 4,5862 \\
media rekaman & 5,7632 & 3,7788 & 4,0892 \\
Kimia & 8,7395 & 5,2741 & 2,9572 \\
Karet & 1,2104 & 3,2949 & 1,0080 \\
Galian & 3,4087 & 3,5760 & 3,8351 \\
Logam Dasar & $-3,0177$ & 7,2283 & 1,8804 \\
Logam & 6,3624 & 8,1641 & 28,6544 \\
Mesin Listrik & 15,4903 & 6,0719 & 11,2772 \\
Kedokteran & 5,1856 & 1,8168 & $-0,7301$ \\
Furniture & & &
\end{tabular}

Sumber: Hasil Olahan

\section{Perhitungan THP Pendekatan Coub Douglas}

Perhitungan TFP pendekatan Coubdouglas menggunakan regresi panel data. Dimana dari hasil regresi didapatkan nilai eror dari yang menjadi pendekatan nilai pertumbuhan TFP

\section{Pemilihan Model Terbaik Pada Panel Data}

Pada metode data panel terdapat beberapa macam model ekonometrika yaitu Pooled Least Square (PLS), Fixed Effect Model (FEM), dan Random Effrect Model (REM). Terdapat beberapa uji yang harus dilakukan dalam menentukan apakah model merupakan PLS, FEM ataupun REM.
Uji Chow untuk menentukan apakah FEM atau PLS dan Uji Hausman untuk menentukan apakah REM atau FEM dan Uji LM untuk menentukan apakah PLS atau REM.

Pada hasil estimasi dapat dilihat bahwa nilai probabilitas dari Uji Chow menunujukan nilai sebesar 0,0000 yang nilainya lebih kecil dari $\alpha$ sebesar $5 \%$ yang berarti model yang harus diambil adalah model FEM dibandingkan PLS. Sedangkan dari uji Hausman didapatkan Prob>0,05 maka model yang terpilih adalah REM. 
Tabel 7 Hasil Uji Chow dan Hausman

\begin{tabular}{lc}
\hline Uji Model Terbaik & $\begin{array}{c}\text { Probabilitas Chi-Sq } \\
\text { Nodel Produksi } \\
\text { Nasional }\end{array}$ \\
\hline $\begin{array}{l}\text { Probabilitas Uji } \\
\text { Chow }\end{array}$ & $0,0000^{*}$ \\
\hline $\begin{array}{l}\text { Probabilitas Uji } \\
\text { Hausman }\end{array}$ & $0,5437^{*}$ \\
\hline $\begin{array}{l}\text { Keterangan : Tanda * menandakan signifikan pada } \\
5 \%\end{array}$
\end{tabular}

\section{Hasil Estimasi Pendekatan Panel Data}

Total faktor produktivitas memiliki dua pendekatan perhitungan parametrik yaitu menggunakan regresi (panel data) dan juga stokastik frontier. Hasil estimasi menunjukan bahwa modal tidak memberikan pengaruh yang signifikan terhadap nilai produksi. Sebaliknya tenaga kerja dan nilai bahan baku memberikan pengaruh signifikan yang ditunjukan dengan nilai probabilitas kurang dari 0,05 dan nilai koefisien sebesar 0,8283 untuk tenaga kerja dan 0,0353 untuk bahan baku.

Hasil estimasi menunjukan bahwa setiap kenaikan tenaga kerja sebesar $1 \%$ maka terjadi perubahan pertumbuhan produksi sebesar $0,035 \%$. Sedangkan peningkatan bahan baku sebesar $1 \%$ akan meningkatkan perubahan pertumbuhan nilai produksi sebesar $0,83 \%$. Hal ini disebabkan sebagian besar industri pengolahan di Indonesia merupakat padat bahan baku dan tenaga kerja. Mayashinta dan Firdaus (2013) mengatakan bahwa industri di Indonesia khususnya tembakau sebagian besar berasal padat tenaga kerja. Jika dilihat dari struktur biaya hampir $90 \%$ digunakan hanya untuk bahan baku dan juga tenaga kerja.
Tabel 8 Hasil Estimasi Model Panel Data

\begin{tabular}{lrr}
\hline Variabel & Koefisien & $\begin{array}{r}\text { Probabili } \\
\text { tas }\end{array}$ \\
\hline LnKapital & 0,03493 & 0,1134 \\
LnTenaga_Kerja & 0,03537 & 0,0109 \\
LnBiaya_Bahan_ & 0,8283 & 0,0000 \\
Baku & & \\
C & $-0,7135$ & 0,0000 \\
R-Square & 0,9414 & \\
& 0,0000 & \\
Prob, F-Hitung & & \\
\hline
\end{tabular}

Pertumbuhan Total Faktor

Produktivitas Industri Manufaktur Indonesia Pendekatan Regresi

Pertumbuhan ouput tidak hanya bersumber dari faktor akumulasi penggunaan input tenaga kerja dan input kapital serta dari produktivitas tetapi juga disebabkan oleh kemajuan teknologi. Secara teoritis, dengan pendekatan regresi kemajuan teknologi yang di gambarkan melalui TFP merupakan residual dari sebuah fungsi produksi. Residual berarti segala input yang dapat meningkatkan pertumbuhan output selain input tenaga kerja dan input kapital.

Hasil penghitungan total faktor produktivitas berdasarkan pendekatan regresi selama periode 2002-2005, 2006-2009, dan 2009-2013 disajikan pada Tabel 13. Selama periode 20032005 hampir semua sektor industri yang termasuk dalam cakupan penelitian mengalami kemajuan teknologi kecuali logam dasar, kayu, galian dan mesin listrik. Total faktor produktivitas tertinggi terjadi di industri alat kedokteran dengan TFP sebesar 8,96 dan terendah di sektor industri mesin listrik sebesar $-6,69 \%$. 
Tabel 9 Pertumbuhan Total Faktor Produktivitas Industri Pengolahan Indonesia Pendekatan Regresi (\%)

\begin{tabular}{lcrr}
\hline Industri & $2003-2005$ & $2006-2009$ & $2010-2013$ \\
\hline Makanan dan minuman & 1,9888 & 2,9808 & 1,2086 \\
Tembakau & 1,2054 & $-20,2141$ & 10,1035 \\
Tekstil & 2,5722 & $-0,1278$ & 12,1701 \\
Pakaian jadi & 2,2943 & 4,9342 & $-1,8229$ \\
Kulit dan barang dari kulit & 3,0106 & $-5,0904$ & 6,1226 \\
Kayu & $-4,2004$ & $-0,6966$ & 3,6039 \\
Penerbitan, percetakan dan reproduksi & 1,4190 & 2,1769 & $-23,7652$ \\
media rekaman & & & \\
Kimia & 3,2770 & $-1,2574$ & 9,4857 \\
Karet & 2,4949 & $-4,4294$ & 8,5600 \\
Galian & $-4,5426$ & 0,5472 & $-2,6019$ \\
Logam dasar & $-2,1632$ & 0,8520 & 9,8667 \\
Logam selain mesin dan listrik & 0,5081 & 2,1865 & 1,9944 \\
Mesin Listrik & $-5,5036$ & 8,6408 & 20,5768 \\
Kedokteran & 8,9602 & $-12,3115$ & $-41,8380$ \\
Furniture & 4,2927 & $-1,5712$ & $-0,9886$ \\
\hline
\end{tabular}

Sumber: Hasil Olahan

Selama periode 2006-2009 yaitu pada saat krisis terdapat banyak industri manufaktur yang memiliki nilai total faktor produktivitas yang negatif. Nilai produktifitas yang negatif bukanlah diartikan sebagai terjadinya penurunan teknologi melainkan dikarenakan adanya penurunan skala usaha yang dapat disebabkan oleh berbagai macam seperti berkurangnya skala produksi akibat krisis.

Industri yang mengalami nilai total produktivitas yang negatif ketika tahun krisis adalah industri tembakau, tekstil, kulit dan barang dari kulit, kayu, karet, kedokteran dan furniture. Sebagian dari industri tersebut merupakan industri ekspor sehingga ketika krisis nilai produksipun menurun. Seperti pada industri tekstil rata-rata pertumbuhan ekspor pada tahun 2006-2009 sebesar -9,30\% dimana penurunan ekspor terjadi sejak tahun 2007.

Periode awal setelah krisis hingga tahun 2013 menunjukan perbaikan pada beberapa industri yang pada periode krisis mengalami nilai TFP negatif. Industri tembakau, tekstil, kulit, kayu, kimia, dan karet yang pada periode krisis bernilai bernilai negatif yaitu $-20,21 ;-0,12 ;-5,09 ;-0,69 ;-1,25$ dan $-4,42 \%$ meningkat menjadi 10,10 ; 12,$17 ; 6,12 ; 3,60 ; 9,48$ dan $8,56 \%$. Hal ini membuktikan bahwa perbaikan ekonomi pasca krisis mampu meningkatkan total faktor produktivitas yang disebabkan meningkatkan skala produksi. Industri kedokteran dan furniture masih mengalami trend yang negatif.

\section{KESIMPULAN}

Sebagian besar industri pengolahan di Indonesia mengalami peningkatan efisiensi kecuali pada beberapa industri seperti pengolahan kayu. Sedangkan untuk pertumbuhan teknologi pada semua industri di Indonesia mengalami peningkatan meskipun nilainya relatif kecil. 
Berdasarkan perhitungan TFP menggunakan SFA maupun regresi pada tahun 2003-2005 sebagian besar Industri mengalami peningkatan pertumbuhan TFP dengan yang tertinggi adalah indutri kedokteran, karet, penerbitan, pakaian jadi, makanan dan minuman. Namun ketika krisis beberapa industri mengalami penurunan pertumbuhan TFP. Hasil tersebut menunjukkan bahwa industri di Indonesia masih sangat rentan terhadap krisis

\section{Saran}

Penggunaan teknologi di Indonesia di sector industri belum menunjukkan peningkatan yang tinggi hal ini dilihat pertumbuhan teknologi yang relatif kecil. Pemerintah dapat melakukan kebijakan untuk mempercepat transfer teknologi baik dari yang telah dipatenkan di Indonesia maupun dari luar negeri.selain itu nilai TFP di Indonesia masih sangat rentan terhadap krisis yang salah satunya disebabkan banyaknya bahan baku yang berasal dari impor. Program subtitusi impor dengan membentuk industri hulu dan hilir diharapakan mampu mengatasi permasalahan bahan baku yang mahal akibat adanya krisis.

\section{DAFTAR PUSTAKA}

Asghar, Ali. 2011. Micro Determinants of Total Faktor Productivity Growth Of Agriculture In Pakistan. $\mathrm{PhD}$ thesis, University of Agriculture

Aswicahyono H. 1998. Total Factor Productivity in Indonesian Manufacturing, 1975-1993. Unpublished PhD thesis, Australian National University, Canberra.

Aswicahyono H. and Hill, Hal. 2002. 'Perspiration' versus 'Inspiration' in Asian Industrialisation: Indonesia before the Crisis,
Journal of Development Studies 38 (3): 138-63.

Coelli T, Rahman S, Colin T. 2003. A Stochastic Frontier Approach to Total Factor Productivity Measurement in Bangladesh Crop Agriculture, 1961-1992. Journal of International Development 15: 321-333.

Constantin PD, Martin DL, Rivera. 2009. Cobb-Douglas, Translog Stochastic Production Function and Data Envelopment Analysis in Total Faktor Productivity in Brazilian Agribusiness. The Flagship Research Journal of International Conference Of the Production and Operations Management Society Volume 2, Number 2.

Fuglie KO. 2010. Economic Research Service of the U.S Department of Agriculture. Indonesia: From Food Security to Market-Led Agricultural Growth.

Jajri I., \& Ismail, R. 2006. Technical efficiency, technological change and total faktor productivity growth in Malaysian manufacturing sector. http://mpra.ub.unimuenchen.de/1956/1/MPRA_pape r 1956.pdf

Jerzmanowski M. 2007. Total Factor Productivity Differences: Appropriate Technology vs. Efficiency, European Economic Review 51: 2080-2110.

Li G, You L, Feng, Z. 2015. The sources of total factor productivity growth in Chinese agriculture: Technological progress or efficiency gain? Journal of Chinese Economic and Business Studies 9(2): 181-203.

Modjo, Muhammad I. 2006. Total Faktor Productivity In Indonesian Manufacturing: A Stochastic 
Frontier Approach. Aberu Discussion Paper 28, 2006

Romer PM. 1986. Increasing Returns and Long-run Growth. Journal of Political Economy 94: 1002-38.

Sharma SC, Sylwester, K., and H. Margono, 2007, Decomposition of Total Factor Productivity Growth in U.S. States, The Quarterly Review of Economics and Finance 47, pp. 215-241.

Sirait, Hisar. 2007. Inefisiensi Teknis, Stagnasi Teknologi, dan Total Produktivitas Industri Manufaktur Usaha Menengah dan Usaha Besar : Pendekatan Sthocastic Production Frontier. Disertasi. Bogor: Program Pascasarjana, Institut Pertanian Bogor
Suphannachart, Waleerat dan Peter Warr. 2010. Total Faktor Productivity in Thai Agriculture Measurement and Determinants. ARE Working Paper No. 2553/1

Swastika DKS.1996. The Measurement of Total Faktor Productivity Growth Using Production Frontier: A Case of Irrigated Rice Farming in West Java. Jurnal Agro Ekonomi. 15(1):1-19.

Vial, Virginie. 2006. Total Factor Productivity In Indonesian Manufacturing: Using Estimates of Elasticities of Value Added with Respect to Labour and Capital, Bulletin of Indonesian Economic Studies (forthcoming). 